\title{
The Diagnosis of Patients with Celiac Disease and Calcium Deficiency
}

\author{
Ilinca Maria Abrudan', Beatrice Kelemen ${ }^{1}$, Ana Maria Girbovan², Carmen Viorica Abrudan ${ }^{3}$, Corina Crisan ${ }^{3}$, \\ Genel Sur ${ }^{4}$, Gabriel Samasca ${ }^{5, *}$ \\ ${ }^{1}$ Department of Molecular Biology, Faculty of Biology, Babes-Bolyai Univesity Cluj-Napoca, Romania \\ ${ }^{2}$ Department of General Medicine, Iuliu Hatieganu University of Medicine and Pharmacy, Cluj-Napoca, Romania \\ ${ }^{3}$ Medical Laboratory Analysis, Children Emergency Hospital, Cluj-Napoca, Romania \\ ${ }^{4}$ Department of Pediatrics II, Iuliu Hatieganu University of Medicine and Pharmacy, Cluj-Napoca, Romania \\ ${ }^{5}$ Department of Immunology, Iuliu Hatieganu University of Medicine and Pharmacy, Cluj-Napoca, Romania \\ *Corresponding author: Gabriel.Samasca@umfcluj.ro
}

\begin{abstract}
Our immunological system is every day under threat from different bacteria, viruses and disease. One of those many diseases is celiac disease. Once this disease affects the metabolism, it produces an imbalance of the electrolyte in blood. Therefore diagnostic tests are very important.
\end{abstract}

Keywords: bone metabolism, celiac disease, diagnostic tests

Cite This Article: Ilinca Maria Abrudan, Beatrice Kelemen, Ana Maria Girbovan, Carmen Viorica Abrudan, Corina Crisan, Genel Sur, and Gabriel Samasca, "The Diagnosis of Patients with Celiac Disease and Calcium Deficiency.” International Journal of Celiac Disease, vol. 4, no. 1 (2016): 16-18. doi: 10.12691/ijcd-4-1-3.

\section{Introduction}

Celiac Disease (CD) is a chronic inflammatory autoimmune disease which consists in changes of the small intestinal mucosa due to gluten intolerance. But to some patients the gradual destruction is more and more severe and it moves to the distal part of the small intestine, and in much severe cases the lesion spreads to the last section of the small intestine, respectively the ileum and to the middle fragment of the large intestine, respectively the colon $[1,2]$. Gluten is a protein from cereals mostly commen in wheat and contains carbohydrates and lipids [3]. Gluten is an albuminoid elastic substance, gray, thick and lax, which is made up from a mixture of gliadin and glutenin [4]. Gluten is also found in rye and barley.

CD has different manifestations from patient to another patient, this differences appear depending on age, length of time and the stage of the disease. Some of the symptoms that manifest in children, adolescent and adults are: diarrhea, nausea, constipation, muscles cramps, weight loss, resting, low height, muscles weakness and they are easily irritable and sad. Some researchers unveil hypocalcemia as a first symptom at an adolescent with an untreated CD [5]. But in the bone metabolism, besides the symptoms from up above the patient presents also: low amounts of vitamin $\mathrm{D}$, low mineral bone density, low bone mass and bone fragility. CD may also affect any organ and tissue without the presence of any symptom; it can grow outside the intestinal area [6].

The diet of a patient diagnosted with CD is one without gluten. The patient must always avoid wheat products, barley and raw. This gluten-free diet (GFD) must be kept the whole life, it plays a very important role in the bone mineralization. The gluten-free products have a very small amount of nutrients, vitamin (B and D) and minerals, including calcium (Ca), iron (Fe), zinc ( $\mathrm{Zn})$ and magnesium (Mg). $\mathrm{Ca}$ is an essential ion and vital to keep the main functions and neuromuscular circulators; it is a cofactor for some of the hormons and enzymes that affect the immune system. In bones and teeth, Ca plays a very important structural role $[7,8]$. GFD is an interdisciplinary problem for both society and family. Therefore the research is being made to discover wheat with small degree or even null properties that can cause poisoning in patients diagnosed with CD [9]. Patients, who don't follow GFD usually present: skeletal disorder, fragile bones that lead to fractures most often and osteoporosis. Osteoporosis is a common disease distinguished by reduced bone strength, which develop the multiple fracture risk [8].

Therefore, the faster the diagnosis of a patient is made, the better they can improve their lifestyle. We established from the start, that our aim was to do a review study of the literature on the main immunological test diagnosis in association with CD and Ca deficiency.

\section{Materials and Methods}

We made a literature review with articles from PubMed database, using "celiac disease" and "calcium” as keywords. We took into consideration only relevant articles in whitch was presented the link between CD and Ca deficiency.

\section{Results}

We found 97 articles about the association between CD and calcium deficiency. The articles contained a total of 
156 evaluation and diagnostic tests of the connection between $\mathrm{CD}$ and Ca deficiency. Dividing them into big categories, we identified the following types: ELISA, IFA, biochemical tests, chemiliminiscence, endoscopy, BMD, absorptiometry and other tests (Table 1). The diagnosis tests for CD revealed a tTG use in most of the cases (Figure 1).

Table 1.The main types of diagnostic tests identified

\begin{tabular}{|c|c|c|}
\hline ELISA for AGA, tTG & 55 & $35 \%$ \\
\hline IFA for AEM & 28 & $18 \%$ \\
\hline Biochemical tests for CA & 3 & $2 \%$ \\
\hline Chemiliminiscence for PTH, IGF1, cortisol & 7 & $4 \%$ \\
\hline Endoscopy & 27 & $17 \%$ \\
\hline BMD & 16 & $10 \%$ \\
\hline absorptiometry & 19 & $12 \%$ \\
\hline Alte teste: tomography of the distal radius and tibia & 1 & $2 \%$ \\
\hline Total & 156 & $100 \%$ \\
\hline
\end{tabular}

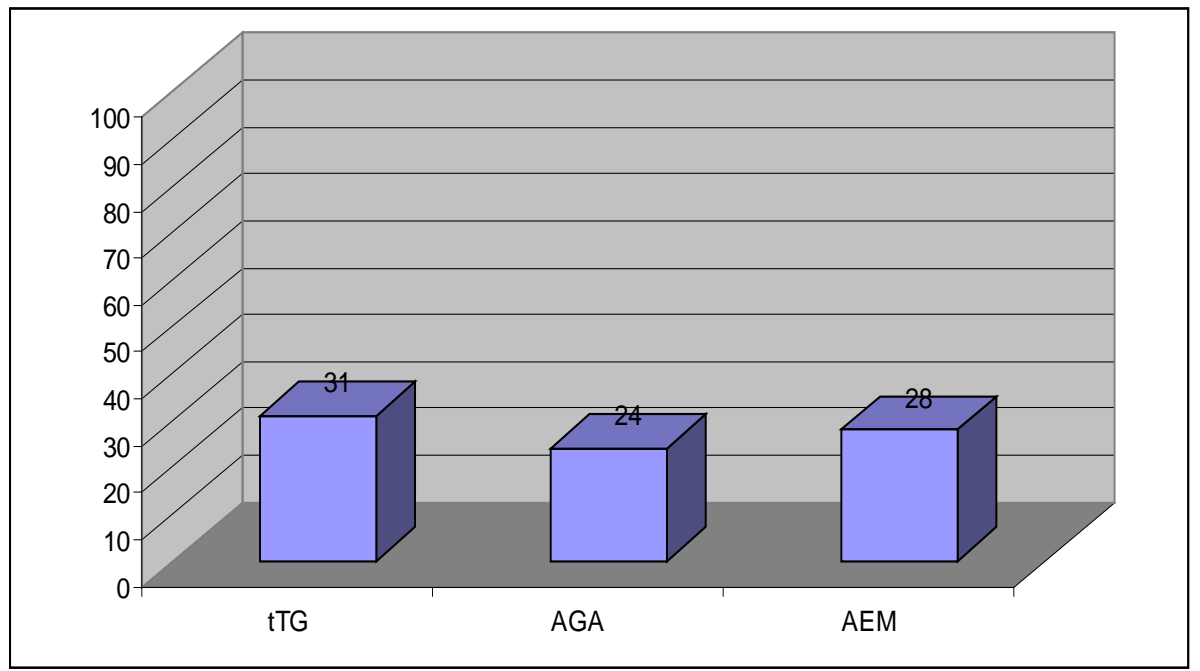

Figure 1. Diagnostic tests in celiac disease

\section{Discussion}

From the presented data it can be observed how important is a precise diagnosis in CD associated with Ca deficiency. First of all, the serological markes for CD are anti-endomysium (AEM) and antibodies transglutaminase tissue (tTG), which have a higher sensitivity and specificity than anti-gliadin antibodies (AGA). But although AGA shows low sensitivity and specificity, from Table 1 we see that AGA is still used in CD screening. If the result is positive for the serological test and there are suspicions of CD from medical point, then the patient will do an endoscopy and a biopsy of the small intestine [10].

Tissue transglutaminase (TG2) is an enyzme that is able to increase the immunological stimulation to gluten and to autoantigen that is the target to the immune response. The tissue transglutaminase autoantibodies own a higher specificity and sensitivity in CD [11]. There are several ways to determine this autoimmune disease. ELISA for tTG is a method that is much easier to use and cheaper than the indirect immunofluorescence for AEM method, although the last method has a higher-level specificity. tTG is a method which presents an upper sensitivity and that's why it is recommended for the screening of CD. If tTG are positive then AEM is a confirmatory test for tTG and for a positive result confirmation it is also recommanded to do an intestinal biospy. The advantages using AEM include higher specificity related with the degree of the villi damage, this can lead up to the development of CD, found in low concentrations in patients with an normal histology of the intestinal mucosa [12].

For the most people that are suspected for calcium deficiency in CD, the person is suppose to submit for (undergo some) medical tests. Calcium is tested in blood. There were found differences between calcemic levels in patients with $\mathrm{CD}$ at the beginning compared to patients with confirmed CD [13]. Besides primary and secondery hypocalcemia, the renal insufficiency is evaluated, vitamin D intoxication and Paget disease. We haven't found any information about bone biopsy usage in literature, which is in accordance with the fact that it is rarley used in medical practice. But this helps very much at diagnosting it. At an evaluation of the renal osteoporosis, a bone biopsy can make the difference between a higher or a lower scale of bone disease [14].

\section{Conclusions}

This disease is a problem that affectes the small intestine. The fact that the patients must followed a GFD, helps them to maintain a better lifestyle. But if the patients 
presents a small amount of electrolyts, in special Ca, prevails the risk for osteoporosis. Therefore, exploring bone metabolism is an important issue in CD. Knowledge of diagnostic tests in this association is also helpful.

\section{Abreviations}

ELISA - The enzyme-linked immunosorbent assay; IFA - Immunofluorescence Antibody Assay; BMD - bone mineral density; PTH - parathormon; IGF1 - Insulin-like growth factor 1

\section{References}

[1] Krupa-Kozak U. Pathologic bone alterations in celiac disease: Etiology, epidemiology, and treatment. Nutrition 2014;30:16-24.

[2] Korkmaz HA, Dizdarer C, Ecevit CO. Hypocalcemic seizure in an adolescent with Down syndrome: a manifestation of unrecognized celiac disease. Turk J Pediatr 2013;55:536-538.

[3] Nenițescu CD. (1980) Chimie organică (volumul II), Editura Didactică și Pedagogică, București.

[4] Chioreanu A, Radulescu G. (1972) Mic Dicționar Enciclopedic, Editura Enciclopedică Română, București.

[5] Caurin Saboya MB, Bonastre Blanco E, Roca Martinez J, Casano Sancho P, Pou Fernández J. Hipocalcemia sintomática como primera manifestació de enfermedad celica en un adolescente. An Pediatr (Barc) 2011;75:425-426.
[6] Sharma M, Singh P, Agnihotri A, Das P, Mishra A, Verma AK, Ahuja A, Sreenivas V, Khadgawat R, Gupta SD, Makharia GK. Celiac Disease: a disease with varied manifestations in adults and adolescents. J Dig Dis 2013;14:518-525.

[7] Agardha D, Rothc B, Lernmarkb A., Stenberg P. Calcium activation of tissue transglutaminase in radioligand binding and enzyme-linked autoantibody immunoassays in childhood celiac disease. Clin Chim Acta 2005;358: 93-103.

[8] Garnier-Lengliné H, Cerf-Bensussan N, Ruemmele FM. Celiac disease in children. Clin Res Hepatol Gastroenterol. 2015;39: 544-551.

[9] Samaşca G, Sur G, Lupan I, Deleanu D. Gluten-free diet and quality of life in celiac disease. Gastroenterol Hepatol Bed Bench 2014:7: 139-0143.

[10] Schuppan D, Zimmer KP. The Diagnosis and Treatment of Celiac Disease. Dtsch Ärztebl Int 2013;110:835-846.

[11] Samaşca G, Pârvan A, Farcău D, Dejica D. Anticorpii antitransglutaminază tisulară. Practică medicală 2010;5:88-91.

[12] Samaşca G, Iancu M, Farcău D, Butnariu A, Pop T, Pîrvan A, Andreica M, Miu N, Cristea V, Dejica D. IgA anti-tissue transglutaminase antibodies, first line in the diagnosis of celiac disease. Clin Lab 2011;57:695-701.

[13] Samașca G, Nechit R, Ponta M, Iancu M, Butnariu A, Farcău D, Andreica M, Dejica D. Statusul Nutrițional Biochimic la copiii cu boală celiacă, Cercetare clinică. Clujul Medical 2010;83:497-503.

[14] Lewiwcki EM. (2015) Osteoporosis: Clinical Evaluation, In: De Groot LJ, Beck-Peccoz P, Chrousos G, Dungan K, Grossman A, Hershman JM, Koch C, McLachlan R, New M, Rebar R, Singer F, Vinik A, Weickert MO, editors. Endotext [Internet]. South Dartmouth (MA): MDText.com, Inc. 